\title{
A Sociolinguistic Study of Miscommunication in Male-female Conversation
}

\author{
Chunqin Zhang ${ }^{1}$ \\ ${ }^{1}$ College of Humanities and Foreign Languages, Xi' an University of Science and Technology, China \\ Correspondence: Chunqin Zhang, College of Humanities and Foreign Languages, Xi'an University of Science \\ and Technology, Lintong, Xi'an 710600 Shaanxi, China. E-mail: javalongbow@163.com
}

Received: June 29, 2013 Accepted: July 14, 2014 Online Published: August 20, 2014

doi:10.5539/ass.v10n17p240 URL: http://dx.doi.org/10.5539/ass.v10n17p240

\begin{abstract}
This paper is intended to study miscommunication between men and women in conversation. Their different conversational styles, way of speaking, topics, talkativeness and the intention of the conversation are identified. Research shows that biological factors and social factors combined have contributed to their different conversational styles and miscommunication.
\end{abstract}

Keywords: miscommunication, conversational styles, biological factors, social factors

\section{Previous Studies on Miscommunication between Men and Women}

Miscommunication has been the subject of a number of studies in the field of linguistics, sociology, communication and women's studies. Tzanne (2000) reports that studies of miscommunication have primarily related to interpersonal relations, communication failure in human-machine interaction, relationship between management and workforce, intercultural communication, and talk-in-interaction in linguistics. In the area of male and female misunderstanding, Tannen (2001) has done extensive gender-linked research and writing that focuses on miscommunications between men and women. Her research is based on conversational analysis of the speech events in real life. Jacobsen (2004) adopts qualitative media analysis to analyze contemporary magazine newspaper cartoons to discover the categories, patterns, and issues in communication breakdowns in male and female relationships. In the book Man Made Language (1980), Spender argues that in patriarchal societies, men control language and language works in their favor. The book illustrates how linguistic determinism interconnects with economic determinism to oppress women in society and explores the assumed deficiencies of women, silencing, intimidation and the politics of naming.

\section{Different Conversational Styles of Men and Women}

\subsection{Ways of Speaking}

Men and women are quite different in speaking style. They tend to use different ways to express themselves, which is one of the major sources of misunderstanding. According to experiments made by linguists, like Robin Lakoff (1989) and Deborah Tannen (2001), women tend to speak in a polite, indirect and affective way, while men speak in a blunt, rough and direct way. Women tend to use more tag questions (Mary is here, isn't she?) and hedges (kind of, sort of, somehow). They also use more question intonation patterns in declarative sentences than men do. For example, women would be more likely to utter So, we will meet at eight with a rise intonation at the end of the sentence. Lakoff claimed that these features of women's speech indicate a degree of uncertainty. (Carroll, 1994) However, they should rather be an expression of politeness rather than uncertainty. Women also show much emotion in their speech by using words such as oh dear, so lovely, such funny, and so on. It is also said that women adopt various pitches to attract the attention of other people since they tend to be ignored in conversation. (Wardhargh, 2000) However, women are born with such a way of speaking which shows their tenderness, politeness and affection. They mostly do so, unconsciously or consciously, as a strategy for conversation mentainance. To men, these ways of speaking may be a little exaggerating and not suit their taste. Since men tend to be direct and less emotional and speak with monotone pitch, women might also think that they are somewhat lack of affection and an indication of not being thoughtful of others. Therefore, when conversing with each other, they may find each other not acceptable. 


\subsection{Topics and Talkativeness}

Men and women also differ in what they often talk about. They actually talk about quite different topics. Women like to talk about their families, feelings, personal experiences, food and clothes. Gossiping is usually considered as the main character of women's talk. Men, however, have quite different topics when they are together. Politics, business, sports are often what they care about. Compared with women, they pay attention to what is big and are usually proud of their topics, national and world news, football, business, etc, which seems to make them manly. Therefore, when men and women are together, their conversation may be a failure. In fact, women tend to like to talk to women, for when they talk to men, it is men who usually dominate the conversation and women have to act as listeners.

Talkativeness of women is another stereotype deeply taken root in people's mind. As a Chinese saying goes, "Three women can perform a play." In English there are also various words to describe women's talkativeness, nagging, gabbing, chattering, prating, etc. Men are often considered to be less talkative and what they say carries weight. Tannen tells a joke which her father used to tell her about the talkativeness of women. One woman sued her husband for a divorce because her husband hadn't talked to her for two years. The judge asked her husband for a reason, and her husband said that he did not want to interrupt her. (Tannen, 2001) However, this is just the stereotype and impression people hold on the talk of the two genders. So far, there is no research indicating that women talk more than men. However, numerous studies prove that men talk much more than women. (Spender, 1980) Women do talk a lot in the same gender group. However, when they are in a mixed-sex conversation, they tend to be reserved. What they do is often listen to men attentively and do some supporting work. For example, they often make responses to men's uttering, and if necessary, introduce topics which cater to men's interests and keep the conversation going. (Spender, 1980) Men, however, tend to try to get the floor to speak and dominate the conversation.

\subsection{Intention}

Men and women have different ways of speaking, topics and tendency towards talkativeness, which leads to different results. Women establish a close friendship with each other since they speak politely and cooperatively while men form a hierarchy of positions from gaining power by competing with others. Therefore, mixed-sex conversation may be a success or failure, for it depends on the degree women tolerate men and how interesting men's topic is. Mostly men and women are usually not to purposefully achieve such an end. They have just developed such a habit and such conversational styles which result in such consequences.

Women like to share their personal feelings and family troubles with others and to share those of others. Through talking with each other about their personal matters, women are easy to establish and maintain a kind of friendly and intimate personal interrelationship (Tannen, 2001). In conversation, women are very cooperative with each other, they speak and allow others to speak. Men, on the other hand, tend to speak if they have something to say, they do not care much about whether others are interested or not or whether they want to speak or not. However, if another man wants to speak, he also just interrupts the man who is speaking and speaks out. In such case, no one is to be blamed since they share the same conversational style. As a result, the conversation is not so consistent as that of women although it can also keep going on. Men like to show themselves off and to look to be knowledgeable. Through conversation, they are to give and receive information and establish their position.

\section{Reasons for Different Conversational Styles of Men and Women}

\subsection{Biological Difference}

Men and women are biologically or sexually different from each other, which has determined their difference in character. Women are gentle and thoughtful since they have the natural responsibility of bearing and taking care of babies who are weak and fragile. They themselves are also weak and play the role of staying at home and taking care of the family. Men, on the other hand, are strong. It is their responsibility to go out to work for food and money and to protect his family. In the earlier days, the biologically or physically determined social roles that men and women play are quite natural and clear. This way of distribution of labor has undergone a long history, and even now it still, to much degree, remains the same. Thus, a convention has been developed and taken root in people's mind. Women do trivial work and depend on men while men are strong, tough and powerful. As a result, men tend to dominate the conversation while women seem to be servile. However, men and women also share some characters since they both are human beings. Conversational styles of men and women are learned in the process of socialization rather than inborn although men are inborn to be more reasonable while women are emotional. Women, when among intimate friends, also speak in a rough way as men do. They think that it is a way to relieve their pressure from trying to behave like a lady when they are in public. 


\subsection{Social Factors}

\subsubsection{Social Structure}

Social structure here refers to the dominant position of men and subordinate position of women. Economy is the basis of social structure. In each social class, upper, middle or lower class, there are men and women. However, in the same social class, men are usually in the dominant position while women in the subordinate position. As discussed in 3.1, biological factors somehow determine the economic and social position of men and women. Since women are economically dependent on men, men are in the dominant position. Thus a social structure came into being, which is just the patriarchal order. Biological difference puts men to the dominant position. Then men reinforce the social structure and their position through the rules they make, and women have to accept it as reality. Therefore this reality is not a completely natural and objective reality but which men perceive it to be. Men think that it is they who create the world. They tend to ignore women and their contribution to the world, even thinking that women are just their belongings. So long as women's economic position does not change and are not strong enough to speak for themselves, the ideology will remain the same.

\subsubsection{Social Norms}

Social norms refer to the rules and conventions that a person should observe as a member of a society so that the society can be kept in order. Once a baby was born, it becomes a member of the society and is exposed to the social structure and norms that are expected to be accepted and observed. The baby has no right to make a choice for itself. Before it is able to perceive what is right or wrong, the adults have decided how the baby should perceive the world, and what it can do and cannot do.

Boys and girls are treated quite differently. Since they have different social roles, they are expected to observe different social norms. Children learn this lesson from the process of socialization. According to behaviorists, children learn their behaviors by imitation, repetition and enhancement. They imitate the behavior of the adults. If the consequence is positive, that is, their parents and people around them praise and encourage them to do so, they will repeat a behavior again and again until it becomes a habit. On the other hand, if the consequence is a negative one, their parents stop them or discourage them to behave like that, the behavior will be weakened and at last diminish. (Brown, 2002)

Women are actually in a dilemma. On one hand, they have to look at men as their norm, while on the other hand, they have to behave like a woman. If a woman works in men's field, such as business, politics, or law, they are expected to speak like men, for only the language of men is considered as powerful. However, when she does speak like a man, people will criticize her for her not being lady-like. Men do not like and even fear that women are like them, which means that they will be as powerful as them and their dominant position will be undermined. (Brown, 2002) Since the concepts about men and women have been stereotyped in people's mind, there are different norms to evaluate them. Men are often evaluated by their occupation and the amount of money they earn. Their looking and characters will not be taken seriously. However, a woman's looking and character are often taken as the norm to evaluate them. How well they can do in other aspects will not be seriously taken into account.

\subsection{Sexism in Language}

Language is a system of symbols people create to communicate ideas and record experiences. So language itself seems neutral. However, since it is not a natural existing but created by human beings and carries their ideas, language has also been socialized and become part of culture. People can organize the elements of language, words, phrases and sentences to convey their ideas. Thus, the language people speak reflects their own ideas about the world and carries subjectivity. Moreover, language inherently contains elements of sexism. (Chambers, 1997) That language is created by men means that it is invented by males, females excluded. Men have been in the dominant position while women are confined to house chores. So women have no opportunity and are not entitled to create language. It is men who have made the language and ask women to accept it and speak it. Therefore, language embodies world-view of men and contains their bias.

Sexism in language can be generally divided into three categories. The first one is that there are more words in language for male, which indicates that it somehow ignores the existence of women. The most typical example is that "man" can refer to male and female while "women" only refers to female. Following are two examples:

(1) Man has to work to live. (2) Love is important for women.

Another example is that the personal pronoun "he" can be used to refer to everyone.

(3) He who hesitates is lost. (4) Each student will do better if he has a voice in the discussion. 
Seeing these examples, we immediately know that "man" and "he" refer to everyone, male or female. However, for a second thought we may notice that female is hidden in them. The second category is that women are regarded as men's belongings. This can be reflected through some customs and language itself. When a woman is married, she will change her surname into her husband's, no matter how famous she is. Moreover, the English words for women are often created through adding prefix or suffix to those for men. It shows that men first created their symbols and then women's with theirs as the center. There are lots of words that are created this way: male, female; host, hostess; hero, heroine; heir, heiress; etc. the last category is that language contains elements that debase women. Stanley had studied North American English and made a statistics on the words connected with sex debauchery. His study shows that 220 such words are connected with women while only 20 are connected with men. (Sun, 1997)

Linguists and feminists have recognized sexism in languages and called for language reform. However, most people do not take it seriously, including women themselves. They just take it for granted and think that ever since it is an effective way to communicate with others, no reform is needed. Most women blindly accept the subordinate position and are content with it. Since the Women's Liberation Movement in 1960s, some efforts have been made by those who want to eliminate sexism in English. Words contain sexism have been changed, chairperson has replaced chairman, fireman has been change into firefighter, etc. However, these words are not popularized except chairperson, which indicates that the original expressions have taken root in people's mind and they are not willing to make the effort to change them. So languages still have their impact on people's way of thinking. Reform cannot succeed when people are not awake to the problems.

\section{Conclusion}

The above analysis presents a general picture of the different communicative styles of men and women. They differ with each other in ways of speaking, which include intonation, pitch, and choice of words and topics. The ways men and women adopt to communicate and what they talk about result from various factors and result in different consequences. Men and women, consciously or unconsciously, cherish different intentions in their communication, and through their ways of speaking and topics they can reach their respective goals. The different communicative styles of men and women are the results of complex factors. They are biologically different from each other and play different social roles. Through discussing the different communicative styles of men and women and the reasons for these differences, this paper is intended that men and women have a better understanding with each other.

\section{References}

Brown, H. D. (2002). Principles of Language Learning and Teaching. Beijing: Foreign Language Teaching \& Research.

Carroll, D. W. (1994). Psychology of Language. California: Brooks/Cole.

Chambers, J. K. (1997). Sociolinguistic Theory. Massachusettes: Blackwell.

Elgin, S. H. (1993). Gender Speak: Men, women, and the art of verbal self-defense. New York: Wile.

Hudson, R. A. (2000). Sociolinguistics. New York: Cambridge UP.

Jacobsen, J. L. (2004). What's the problem? Exploring male/female communication breakdowns through print cartoons. Paper presented at the International Association for Relationship Research Conference, Madison.

Lakoff, R. (1989). Talking Power: The Politics of Language in Our Lives. Harper Collin.

Spender, D. (1980). Man Made Language. London: Routledge.

Sun, R. J. (1997). Xing Bie Yu Yu Yan. Jiang Su Educational Press.

Tannen, D. (2001). Ni Wu Hui Le Wo - Jiao Tan Zhong De Nan Ren He Nv Ren (You Just Don't Understand Men and Women ) (Tans. Zhou Hong \& Zhu Wanjin). Beijing: Beijing UP.

Tzanne, A. (2000). Talking at cross-purposes: the dynamics of miscommunication. Philadelphia: John Benjamins Publishing Company. http://dx.doi.org/10.1075/pbns.62

Wardhaugh, R. (2000). An Introduction to Sociolinguistics. Beijing: Foreign Language Teaching and Research.

\section{Copyrights}

Copyright for this article is retained by the author(s), with first publication rights granted to the journal.

This is an open-access article distributed under the terms and conditions of the Creative Commons Attribution

license (http://creativecommons.org/licenses/by/3.0/). 